\title{
Altered Calcium Metabolism in Epileptic Children on Anticonvulsants
}

\author{
JOHN HUNTER， J. D. MAXWELL， D. A. STEWART，VALERIE PARSONS， ROGER WILLIAMS
}

British Medical fournal, 1971, 4, 202-204

\section{Summary}

A survey of 105 epileptic children aged $10-16$ years at a residential school who were taking anticonvulsant drugs showed reduced serum calcium levels in $30 \%$ and a raised serum alkaline phosphatase in $24 \%$. Urinary D-glucaric acid excretion, a quantitative index of hepatic enzyme induction, was raised in $94 \%$ of the children, and statistical analysis showed a significant inverse correlation with the level of serum calcium. These findings give further support for the view that an important factor in the development of the hypocalcaemia and occasional clinical osteomalacia in epileptics on anticonvulsant drugs is an alteration of vitamin-D metabolism in the liver as a result of microsomal enzyme induction. As a consequence there is an increased requirement for vitamin $D$ which may not be met by average intakes in Britain.

\section{Introduction}

Anticonvulsant drugs such as phenobarbitone, phenytoin, and primidone are known to cause induction of hepatic microsomal enzymes (Conney, 1967) and an increased breakdown of vitamin $\mathrm{D}$ in the liver has recently been implicated in the aetiology of the osteomalacia which has been reported in epileptic patients on these drugs (Dent et al., 1970; Richens and Rowe 1970). In a study of adult epileptics these workers showed a significant relationship between serum calcium levels and the total dosage of anticonvulsant drugs taken. They also described in the rat that the hypercalcaemia and renal calcification produced by vitamin $\mathrm{D}$ intoxication could be reduced by the simultaneous administration of phenobarbitone. Though direct assay of microsomal enzymes in liver biopsy specimens is possible in man, it is rarely feasible. However, we have recently shown that it is possible to assess microsomal enzyme activity quantitatively by measurement of the urinary excretion of D-glucaric acid, a product of the glucuronic acid pathway of the liver (Hunter et al., 1971a). We have used this method in the present study to determine the relationship of hepatic enzyme induction to the level of serum calcium and other biochemical criteria of osteomalacia in a series of 105 children with epilepsy at a residential school.

\section{Methods}

Serum calcium, phosphate, and alkaline phosphatase values were determined by means of the SMA 12/60 AutoAnalyzer in

Medical Research Council Group on Metabolism and Haemodynamics of Liver Disease, King's College Hospital and Medical School, London SE5 8RX

JOHN HUNTER, M.B., M.R.C.P., Research Fellow

J. D. MAXWELL, M.B., M.R.C.P., Honorary Lecturer in Medicine D. A. STEWART, B.SC., Research Biochemist

ROGER WILLIAMS, M.D., F.R.C.P., Director of M.R.C. Group and Consultant Physician

Department of Chemical Pathology, King's College Hospital Medical School, London SE5 8RX

VALERIE PARSONS, M.sc., Senior Biochemist non-fasting venous blood samples taken between 9 and 11 a.m. If the serum specific gravity differed from 1027 the value for the serum calcium was corrected accordingly (Dent, 1962). The isoenzymes of alkaline phosphatase were separated by electrophoresis on polyacrylamide gel (Canapa-Anson and Rowe, 1970), the relative proportions of bone and liver alkaline phosphatase being determined visually.

The concentration of $\mathrm{D}$-glucaric acid in a sample of urine obtained at the same time was determined by the inhibitory effect of glucarolactone, to which D-glucaric acid is converted by heating at $\mathrm{pH} 2$, on $\beta$-glucuronidase as described by Marsh (1963). The result was related to the concentration of creatinine determined in the same urine sample-a ratio which we have previously found both in epileptic and in normal subjects to correlate closely with the total daily D-glucaric acid excretion when measured in a complete 24-hour urine collection $(r=$ 0.97). The results were compared with values found in a control series of urine samples obtained from 15 children aged 10-15 years who were resident in a home for the mentally retarded, and on no drug therapy.

\section{Results}

The 105 children investigated, aged 10-16 years, included 60 boys and 45 girls. Many were of subnormal intelligence, and it was not possible to obtain individual dietary histories, but according to their supervisors none had noticeable food fads, and calculation of the vitamin D content of their diet over two separate weeks indicated an intake of 140-290 IU daily.

The results of the biochemical screening showed that the serum phosphate value was within the normal range in every instance, the mean value for the group being $3.8 \mathrm{mg} / 100 \mathrm{ml}$ (range 2.5-4.8). Serum alkaline phosphatase levels were raised in 25 children to above $295 \mathrm{mU} / \mathrm{ml}$, the upper limit of normal for this age group (Bauer and De Vino, 1969). The highest level was $910 \mathrm{mU} / \mathrm{ml}$, and nine children had levels above 500 $\mathrm{mU} / \mathrm{ml}$ (see Fig.). In every patient with values above 295 $\mathrm{mU} / \mathrm{ml}$ electrophoresis showed that the percentage of bone isoenzymes was very high, comprising $85-100 \%$ of the total amount of alkaline phosphatase present. In only nine patients was the liver isoenzyme the dominant one, and in all these the total serum level fell within the normal range.

In 31 children ( 14 boys and 17 girls) the serum calcium was below $9 \mathrm{mg} / 100 \mathrm{ml}$, which is regarded as the lower limit of the normal range for the SMA 12/60 AutoAnalyzer (G. Walker, personal communication, 1971). Six children had a serum calcium of less than $8.5 \mathrm{mg} / 100 \mathrm{ml}$, and in four of these the calcium phosphate product $(\mathrm{Ca} \times \mathrm{P})$ was below $30 \mathrm{mg} / 100 \mathrm{ml}$, the lower limit of normal (Fraser and MacIntyre, 1970). In three of these children, as well as in the two with a normal $\mathrm{Ca} \times \mathrm{P}$ product, the serum alkaline phosphatase was markedly raised $(298-640 \mathrm{mU} / \mathrm{ml})$. These six children were considered to have biochemical osteomalacia. All had been on anticonvulsant therapy for at least eight years, and though most of the pupils in the school are of British descent, this group included two West Indians and one Italian. Two of the others had been resident at the school for less than 12 months.

A detailed record of the present anticonvulsant regimen and of the duration of therapy was taken in each case. The length of drug treatment varied widely from 2 to 15 years, as did the current dosage of drugs. In many of the children control of 


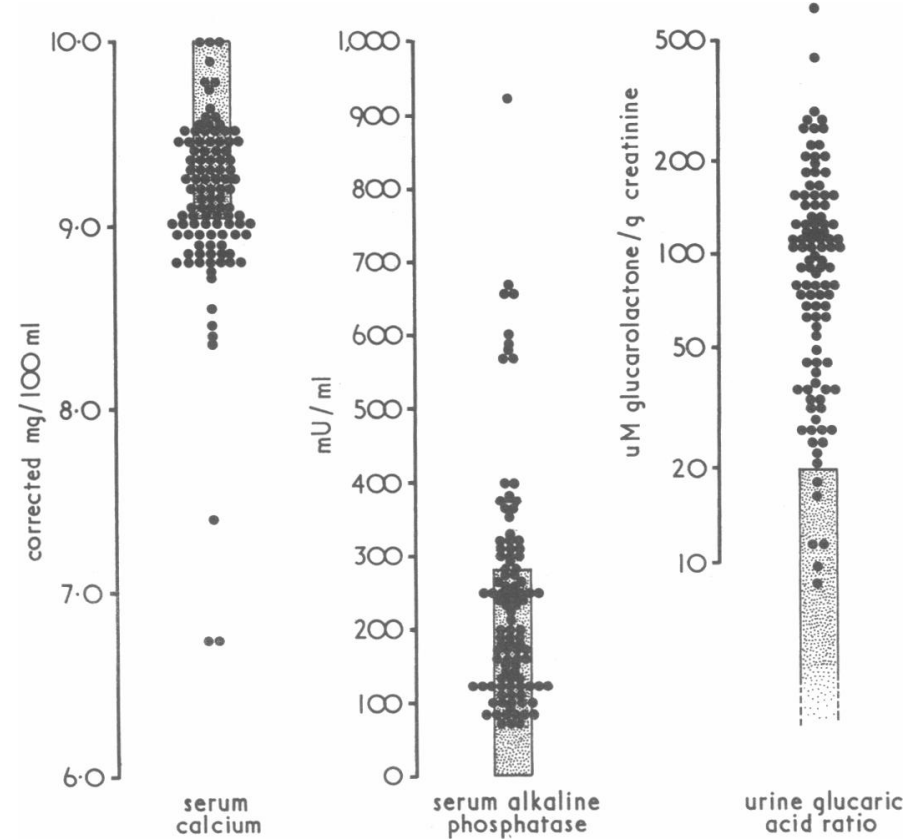

Values for serum calcium, alkaline phosphatase, and urinary glucaric acid excretion in 105 children with epilepsy shown in relation to the normal range (hatched area).

fits had finally been achieved only by the use of several drugs in combination. With the simple scoring scheme of Richens and Rowe (1970) an index of the total daily dose of drugs was calculated for each child, but no correlation could be detected between this and the serum calcium level $(r=-0 \cdot 14$, $\mathrm{P}>0 \cdot 1)$.

\section{Relationship to Urinary D-glucaric Acid}

Increased concentrations indicating a raised total urinary excretion of $\mathrm{D}$-glucaric acid were found in 99 of the 105 children. Four of the six children with values within the normal range had stopped anticonvulsant drugs several months previously because they had been free of fits for some years, and two were currently on small doses only. The increases in D-glucaric acid excretion were often considerable, the highest being $631 \mu \mathrm{M} / \mathrm{g}$ creatinine as compared with a mean in control subjects of $12 \mu \mathrm{M} / \mathrm{g}$ (see Fig.). The six children with biochemical evidence of osteomalacia all had a raised urinary D-glucaric acid, though the range of levels was wide (66-279 $\mu \mathrm{M} / \mathrm{g})$.

Statistical analysis showed a significant correlation between the concentration of D-glucaric acid and the serum calcium level $(r=-0.275, \quad P<0.01)$. This correlation was slightly higher when those on anticonvulsant drugs for more than eight years were considered separately $(n=69, r=-0.312$, $\mathbf{P}<0.01$ ), and an analysis of those on treatment for a shorter period than this failed to show a significant correlation $(\mathbf{n}=33, \mathbf{r}=-0.087, \mathbf{P}>0.1)$. No correlation could be detected between urinary D-glucaric acid and serum alkaline phosphatase levels $(r=-0.040, P>0 \cdot 1)$.

\section{Discussion}

The frequency of biochemical abnormalities in this series of epileptic children-namely, $30 \%$ with hypocalcaemia and $24 \%$ with a raised alkaline phosphatase-is very similar to that reported by Richens and Rowe (1970). In their series of 160 adults with epilepsy $22.5 \%$ had serum calcium levels below $9 \mathrm{mg} / 100 \mathrm{ml}$, and $29 \%$ had raised alkaline phosphatase levels. Unlike these workers, however, we were unable to find any correlation between reduction in serum calcium and the total daily dose of anticonvulsant drugs that the patient was receiving. A possible explanation for this is that many of our patients were on combinations of drugs, including some of the less frequently used ones, such as carbamazepine and sulthiame, whose inducing properties are unknown.

The high levels of D-glucaric acid found in virtually all the epileptic children in this survey are indicative of pronounced induction of the hepatic microsomal enzymes. Though the exact step at which the glucuronic acid pathway in the liver is stimulated is uncertain we have been able to show a close relation between $\mathrm{D}$-glucaric acid excretion and the dose of inducing drugs taken. There is also a significant inverse relationship to the lowering of plasma bilirubin in epileptics which may be another consequence of microsomal enzyme induction (Hunter et al., 1971a). Furthermore, in guinea-pigs, which like man are unable to synthesize ascorbic acid (which in other mammals is the end product of the glucuronic acid pathway), we have found a highly significant relationship between the urinary excretion of D-glucaric acid and the total liver content of the microsomal enzyme cytochrome P450 (Hunter et al., 1971b). In the present study, therefore, the significant correlation found between urinary D-glucaric acid and serum calcium level is strong supporting evidence, though indirect, for the suggestion that enzyme induction is the underlying cause of the hypocalcaemia associated with anticonvulsant therapy.

Vitamin $\mathbf{D}$ is excreted largely as an inactive glucuronide, and this process may be expected to increase with microsomal enzyme induction. However, it is also known that cholecalciferol (D3), the main form of the vitamin in man, is converted in the liver to a metabolite with greater antirachitic activity-namely, 25-hydroxycholecalciferol (Ponchon et al., 1969). Induction could lead to an increased production of this metabolite but the situation is complex for it has also been shown recently that 25 -hydroxycholecalciferol is further metabolized in the liver and other organs to more polar compounds (Cousins et al., 1970) such as 1,25-hydroxycholecalciferol (Lawson et al., 1971) and 21,25- and 25,26-dihydroxycholecalciferol (Suda et al., 1970a, 1970b). The first of these metabolites has greater antirachitic activity than 25-hydroxycholecalciferol but the two other compounds have much less. Thus induction could result in a change in the normal breakdown of vitamin $D$ with the production of less active compounds. Similar changes in the metabolism of cortisol in man have also been described after the administration of barbiturates and phenytoin, with increased hydroxylation to $6 \mathrm{~B}-$ hydroxycortisol-a more polar and probably less active compound (Werk et al., 1964; Kuntzman et al., 1968).

Vitamin $\mathrm{D}$ deficiency, though generally rare in Britain, has been described in immigrants (Dunnigan et al., 1962; Benson et al., 1963), and it may be relevant that three of the six epileptic children with biochemical evidence of osteomalacia were immigrants. The daily amount of vitamin $\mathrm{D}$ available to these children, estimated from the content of the school diet, was 140-290 IU, but as already mentioned it was difficult to assess how closely the actual intake was related to this. Lumb et al. (1971) estimated that many people in north-west England have a dietary intake of only 30-60 IU, though Dent and Smith (1969) regarded $75 \mathrm{IU}$ to be the minimum adult requirement. In Britain, with such levels of dietary intake and with relatively little exposure to sunlight to compensate, it is not perhaps surprising that deficiency arises when demands for the vitamin are increased following the hepatic enzyme induction which results from anticonvulsant therapy. This may explain why there have so far been no reports of this complication from the U.S.A. or Canada, where the fortification of foodstuffs with vitamin $\mathrm{D}$ provides a large daily intake-often as much as 2,000-3,000 IU (American Academy of Pediatrics, 1963). 
We are grateful to Dr. James Bowe, Medical Director of Lingfield Hospital School, for his support of this study. We are also indebted to Dr. P. J. N. Howarth and the staff of the chemical pathology laboratory, King's College Hospital, for their help with the biochemical screening, and to Dr. R. P. Knill-Jones for assistance with statistical analysis.

\section{References}

American Academy of Pediatrics. Committee on Nutrition (1963). Pediatrics, 31, 512 .

Bauer, S., and De Vino, T. (1969). Technicon International Congress, 3, 3i.

Benson, P. F., Stroud, C. E., Mitchell, N. J., and Nicolaides, A. (1963) British Medical fournal, 1, 1054

Canapa-Anson, R., and Rowe, D. J. F. (1970). Fournal of Clinical Patho-

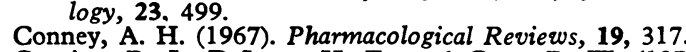

Cousins, R. J., DeLuca, H. F., and Gray, R. W. (1970). Biochemistry, 9, 3649.

Dent, C. E. (1962). British Medical fournal, 2, 1419.
Dent, C. E., Richens, A., Rowe, D. J. F., and Stamp, T. C. B. (1970).

Dent, C. E., and Smith, R. (1969). Quarterly fournal of Medicine, 38, 195

Dunnigan, M. G., et al. (1962). Scottish Medical fournal, 7, 159.

Fraser, R., and MacIntyre, I. (1970). In Biochemical Disorders in Human Disease, ed. R. H. S. Thompson, and D. H. P. Wooton. London, Churchill.

Hunter, J., Maxwell, J. D., Carrella, M., Stewart D. A., and Williams, R. (1971a). Lancet, 1, 572.

Hunter, J., Maxwell, J. D., and Williams, R. (1971b). Lancet, 2, 47.

Kuntzman, R., Jacobson, M., Levin, W., and Conney, A. H. (1968). Biochemical Pharmacology, 17, 565.

Lawson, D. E. M., Fraser, D. R., Kodicek, E., Morris, H. R., and Williams, D. H. (1971). Nature, 230, 228.

Lumb, G. A., Mawer, E. B., and Stanbury, S. W. (1971). American fournal of Medicine, 50, 421 .

Marsh, C. A. (1963). Biochemical fournal, 86, 77.

Ponchon G., Kennan, A. L., and DeLuca, H. F. (1969). Fournal of Clinical Investiration, 48. 2032.

Richens, A., and Rowe, D. I. F. (1970). British Medical fournal, 4, 73.

Suda, T., et al., (1970a). Biochemistry, 9, 2917.

Suda, T., et al, (1970b). Biochemistry, 9, 4776

Werk, E. E., Macgee, J., and Sholiton, L. J. (1964). Foumal of Clinical Investigation, 43, 1824 .

\title{
Hyposensitization with Dermatophagoides pteronyssinus Antigen: Trial in Asthma Induced by House Dust
}

\author{
A. P. SMITH
}

British Medical fournal, 1971, 4, 204-206

\section{Summary}

A double-blind clinical trial of hyposensitization with aqueous extracts of Dermatophagoides pteronyssinus (the housedust mite) and human skin scales showed a substantial improvement in symptoms in 11 asthmatics allergic to house dust treated with the D.pteronyssinus extract and a reduction in their need for other therapy. Five patients were well for a year but six relapsed. These results contrasted with the generally unfavourable course of the patients treated with the extract of human skin scales. Asthma due to housedust allergy may be substantially improved by hyposensitization with $D$. pteronyssinus extract.

\section{Introduction}

The role of the house-dust mite (Dermatophagoides pteronyssinus) as the major allergen in house dust has been well established (Voorhorst et al., 1967; Maunsell et al., 1968; Morrow Brown and Filer, 1968; Pepys et al., 1968). Patients known to be allergic to house dust also show marked skin, nasal, and bronchial allergy to the house-dust mite. The treatment of house-dust allergy by hyposensitizing injections has been disappointing (McAllen, 1961; British Tuberculosis Association, 1968), presumably because of the low concentration of mite antigen in the extracts used. We therefore carried out a double-blind trial to determine the hyposensitizing effects of injections of aqueous extract of $D$. pteronyssinus in a small group of patients with asthma induced by house dust.

Pulmonary Research Unit, King's College Hospital, London SE5 9RS A. P. SMITH, M.B., M.R.C.P., Lecturer

\section{Patients and Methods}

Twenty-two patients were selected who had perennial asthma, with or without rhinitis; attacks of asthma on contact with house dust (as in sweeping or making beds) and frequent nocturnal and early morning attacks of asthma; an immediately positive result to a prick test with $1: 10,000$ extract of $D$. pteronyssinus; no history of other allergies; and negative skin tests to Aspergillus fumigatus, other moulds, pollens, and animal fur. Further information about them is presented in Table I. All had suffered from asthma for many years.

TABLE 1-Distribution of the Patient's Characteristics between the Two Treatment Groups

\begin{tabular}{|c|c|c|c|}
\hline & & Mite-treated Group & Control-treated Group \\
\hline $\begin{array}{l}\text { Total No. } \\
\text { Age range (years) } \\
\text { Males/females } \\
\text { Smokers } \\
\text { Atopic family histor } \\
\text { Allergic rhinitis } \\
\text { Severity of asthma: } \\
\text { Mild } \\
\text { Moderate } \\
\text { Severe } \\
\text { Very severe } \\
\text { No. on steroid } \\
\text { No. on disodium cro }\end{array}$ & 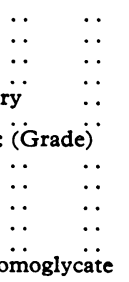 & $\begin{array}{c}11 \\
11-47 \\
5 / 6 \\
4 \\
10 \\
10 \\
0 \\
5 \\
4 \\
2 \\
3 \\
1\end{array}$ & $\begin{array}{r}11 \\
13-48 \\
9 / 2 \\
1 \\
9 \\
8 \\
0 \\
0 \\
3 \\
7 \\
1 \\
4 \\
1\end{array}$ \\
\hline
\end{tabular}

The grading of asthma before entering the trial was based on the number of days off work in the previous six months, the severity of breathlessness, the frequency of nocturnal attacks, the frequency with which an aerosol bronchodilator was used during the month before treatment, and the type of therapy previously received by the patient.

One group of 11 patients received house-dust mite extract and the other 11 patients an extract of human skin scales. The mite extracts were prepared by Dr. Kate Maunsell in the way she has described (McAllen et al., 1970), and the control extracts were prepared in the same fashion. There was no loss of skin-reacting property in the mite extract after heating, and the strength was unimpaired after storage at room temperature for 12 months. 